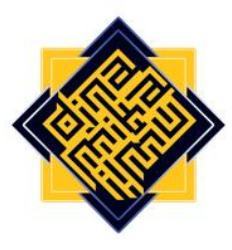

\title{
Management Techniques for Organizational Rumor and Gossip in Schools
}

\author{
Bünyamin HAN \\ Kütahya Dumlupınar University \\ e-mail:bunyaminhan@gmail.com
}

\begin{abstract}
This research aims to determine the techniques for effective management of organizational rumor and gossip in schools. Rumors are informal conversations circulating among the employees of the organization towards an event. Gossips are informal evaluative speech about people who are not present there. Rumors and gossips are common informal conversations, which should be managed by school administration. In this term, this research investigates the ways of managing them. The study is a phenomenological qualitative research carried out by conducting semi-structured interviews with 33 teachers in Diyarbakır, Turkey. The data were analyzed by using content analysis technique and some themes and categories were created. According to the research results, school administration should organize some informative seminars on awareness, communication and values in order to reduce the harmful aspects of rumor and gossip. The school administration should adopt a transparent management approach, establish a feedback mechanism, provide effective communication, operate formal communication channels and react to those who spread harmful rumor and gossip. The rumors and gossips can be used for organizational purposes such as; improving intimate relationships, recognizing the organization and employees, improving group cooperation and sincerity, understanding the hidden side of events, learning innovations and changes, learning how changes and practices are perceived, identifying deficiencies and problems in jobs, learning employee expectations.
\end{abstract}

Keywords: rumor, gossip, informal communication, teacher, school 


\section{A. Introduction}

Human beings have the tendency of communicating with others wherever they live. Especially when people are staying and working in the same environment the interaction among them, therefore, becomes inevitable. People have to accomplish a duty in the organizations, which force them to work cooperatively. In cooperation, people interact and communicate with other employees in different types. In that context, the share of information and feelings constitutes organizational communication.

It is possible to mention different types of communication within the organizational environment. The most common examples of informal communication in organizations are rumors and gossips. Organizational rumor can be defined as unproven information that emerged in the context of an uncertainty, danger or potential threat in an organization and help the employees to make sense of these situations and get rid of the risks (DiFonzo \& Bordia, 2007). Fearn-Banks (2007) defines rumor as the information that has not been proven to be reliable and has no reliable source. On the other hand, organizational gossip can be defined as the social conversations about the occurrence, change and continuation of social networks in the context of the formation of group unity and generally about the people who are not present in the conversation environment (Difonzo \& Bordia, 2007). In gossip, people share both positive and negative personal information in the sincere environments about third parties who are not present (Foster, 2004). Kurland and Pelled (2000) also define gossips as informal and evaluative speeches in a group that is usually not more than a few people and is about the person who is not usually there at time of conversation. In gossip, a sender communicates to a receiver about a target who is absent or unaware of the content (Dores et al. 2020). Rumors and gossips are interrelated with each other but they are different in terms of their content and functions. While the content of the rumors may be about individuals, situations, jobs, and institutions, the content of the gossips is definitely private issues regarding people and their lives (Lind et al., 2007; Adkins, 2017; Han, 2020). In terms of their functions in the organization, rumors are basically used to obtain information and to make sense, while gossips have the function of organizing social relations and learning norms (Stewart \& Strathern, 2004; Rosnow \& Foster, 2005; Crescimbene, Longa \& Lanza, 2012; Han, 2020).

Informal communication can be highly effective in organizational life, in favor of or against the organization. Informal communication is seen as a complementary element of formal communication with its multiple benefits in organizations (Sabuncuoğlu \& Gümüş, 2008). However, when the process of informal communication is ignored or mismanaged, it can cause disasters in organizations by disrupting the organizational climate. Rumor and gossips circulating among the teachers constitute a large part of the communication in schools (Dağlı \& Han, 2018). Therefore, they are considered as very important issues in organizational researches. Being affected by many organizational factors, informal communication sometimes gets out of control, and takes a toxic structure and may damage the relations among the employees (Bektaş \& Erdem, 2015). In that case, school administrators have responsibilities to control these informal communication channels (Atak, 2005) and use them in favor of the organization (Bahar, 2016). In schools, informal 
communication may have organizational benefits in terms of supporting formal communication (Ünal-Çolak, 2012). For example, informal communication can be used as a motivation tool by reducing the stress in organizations (Bektaş \& Erdem, 2015). On the other hand, informal communication may bring more harm than benefit when mismanaged (Ünal-Çolak, 2012). For that reason, the concept of management of informal communication becomes important. In this sense, Crampton, Hodge and Mishra (1998) highlighted the importance of managing the rumors to reduce their potential harm for both employers and organizations. Allaoui (2018) also emphasizes using different strategies and philosophies to manage gossip in organizations. Therefore, since it is almost impossible to manage the organization only through formal channels, administrators should use informal communication channels in line with organizational aims. When the research regarding to the management of rumor and gossip in the related literature are examined (Askarizadeh \& Ladani, 2021; Zhang, et al., 2019; Chen, 2019; Paek \& Hove, 2019; Zeng, Chan \& Fu, 2017; Bao et al., 2013; Wang, 2014; Tripathy, Bagchi, \& Mehta, 2010; Ribeiro \& Blakeley, 1995), it can be concluded that there are rare research on their management in educational context that necessitates more research on this topic.

Schools are among the organizations where human interaction is experienced utmost. The teachers frequently use informal communication in their relations. In this respect, it can be claimed that these two types of communication have the potential to harm organizational functioning of schools when not managed properly. It is also possible to claim that when the rumor and gossip are effectively managed, they can be used in favor of the school management in a way that will contribute to the organizations. Therefore, exploring the techniques to be used in the management of rumor and gossip is considered to have importance in educational administration. Accordingly, the research questions are following:

1) How do you think the harmful aspects of the rumors in schools can be reduced?

2) How do you think the positive aspects of the rumors in schools can be used in favor of the organization?

3) How do you think the harmful aspects of gossip in schools can be reduced?

4) How do you think the positive aspects of gossip in schools can be used in favor of the organization?

\section{B. Literature Review}

Employers in an organization use different types of communication in organizational life. The communication used in organizations can be classified as formal and informal communication in terms of its structure (Michelson \& Mouly, 2004; Sabuncuoğlu \& Gümüş, 2008; Gönen, Öztürk \& Efilti, 2008; Bursalığlu, 2011; Güllüoğlu, 2012; Ünal-Çolak, 2012; Ergin, 2014). Formal communication can be defined as the bidirectional flow of news, information and decisions (Ergin, 2014), among the steps and the authorities in the hierarchy (Bursalıoğlu, 2011) in a predetermined way within the organizational rules and in line with the objectives of the organization (Sabuncuoğlu \& Gümüş, 2008). In this sense, formal communication consists of relations and channels that occur depending on 
organization's formal structure (Ünal-Çolak, 2012: 130). On the other hand, informal communication can be defined as the relationships among individuals and groups (Bursalıoğlu, 2011; Ergin, 2014), not connected to formal regulations but resulting from the natural requirements of individuals (Ünal-Colak, 2012), to meet the social needs of the employees (Bektaş \& Erdem, 2015). Employees use informal communication to increase their social relations in the groups (Uğurlu, 2014). Therefore, it can be claimed that informal communication affects organizational and group interaction.

The researchers focus on creating a positive organizational climate with the management of informal communication. Hirschhorn, (1983) states that rumors can be managed by making an open and collective planning based on information sharing within the organizational climate. According to him, such a climate eliminates uncertainty, improves credibility and enables the discovery of both individual and organizational characteristics. Liff and Wikström (2021) have found that the ability of managers to include informal information in their daily work can create trust in organizations. Arabacı et al., (2012) also emphasized the positive organizational climate in management of informal communication in schools. Organizations should not ignore rumors that could damage the image of their organizations. Rumors can waste time, reduce productivity, and lower morale (Rahmani, (2018). Managers must take responsibility and must respond to rumors at workplaces before the situations get out of control (Han, 2019). Pheko (2018) focuses on rumors and gossip as 'tools' used by perpetrators of workplace bullying and mobbing. Şantaş et al., (2018) have found a relation among organizational revenge and job stress.

The research findings in the literature show that organizational rumor and gossip, which are among the informal forms of communication, have both positive and negative functions for organizations and the employees (Kimmel, 2004; Michelson \& Mouly, 2004; Stewart \& Strathern, 2004; Brown \& Napier, 2004; Rosnow \& Foster, 2005; DiFonzo \& Bordia, 2007; Fearn-Banks, 2007; Fine \& Ellis, 2010; Kieffer, 2013; Zhao, Yin \& Zong, 2016; Rahmani, 2018). Since a large part of interpersonal communication is about personal features of other people (Han \& Dağll, 2018) organizational communication research should focus on rumors and gossips in schools. This research will contribute the existing literature and will enable school administrators to use appropriate techniques in the management of organizational rumors and gossips.

\section{Research Methodology}

This research aims to detect the management strategies of rumor and gossip in schools based on the teacher opinions. For that reason, this study is designed as a phenomenology research pattern. The phenomenology pattern focuses on phenomena that we are aware of but do not have an in-depth and detailed understanding (Yıldırım \& Şimşek, 2013). Some other researchers (Patton, 2014; Miles \& Huberman, 2016; Ersoy, 2017; Yin, 2017) also emphasize the role of phenomenology research in getting detailed rich data. By using phenomenology, this research aims to emphasize the perception and experiences of teachers from their point of views. 


\section{Study Group of the Research}

In order to explore the harmful and beneficial aspects of rumors and gossips in schools, the teachers were consulted for their opinions. Typical case sampling method was used in order to determine the schools in the scope of the research. Thus, interviews were planned with teachers from schools in Diyarbakır, Turkey. The interviews were carried out in the public schools with 33 volunteer teachers. The interviews were conducted in the schools and took 15-20 minutes.

Some of the personal characteristics of the teachers who participated in the research were as follows: From the 33 teachers 14 were females and 19 males. The seniority of the participants varied between 2 and 20 years. In terms of educational status, 10 had undergraduate and 23 graduate education. In terms of school type, 11 of them work in the village schools, 6 in the district center and 16 in the city center. Collecting the data from teachers in terms of different gender, professional seniority, educational status and type of school enabled rich data for the research. All the participants were full-time employed and spend nearly 5 to 8 hours in a day at school. In that case, the participants are thought to have enough experience on rumors and gossips circulating in school.

\section{Interview Forms}

In this research, a semi-structured interview form was prepared based on the related literature to use in collecting data during the interviews. Türnüklü, (2000) advices using semi-structured interview technique due to its having a more flexible structure and being a more convenient data collection technique in educational researches. The semi-structured interview technique was prepared in this research because it enables freedom to ask additional questions in order to get more detailed information about the research questions (Yıldırım \& Şimşek, 2013). The interview form used in this research consisted of four main questions. In the form, there were two open-ended questions related to rumor; 1) how do you think the harmful aspects of the rumors in schools can be reduced? 2) how do you think the positive aspects of the rumors in schools can be used in favor of the organization? In the interview form, there were two open-ended questions regarding gossip; 1 ) how do you think the harmful aspects of gossip in schools can be reduced? 2) how do you think the positive aspects of gossip in schools can be used in favor of the organization? The interviews were detailed with probe questions in case of necessity.

\section{Data Collection and Analysis Process}

Before the interviews, the researcher informed the teachers about the purpose of the research. Then the teachers were interviewed face to face in the schools during their break time. During the interviews, the researcher made some explanations and asked probes to obtain detailed information. In this way, the teachers wrote their opinions with handwriting on the interview forms themselves. After each interview, the researcher consulted the participant about the intended meaning in order to minimize the misinterpretations. 
The data were analyzed by using content analysis technique. In the data analysis process, the method of Miles and Huberman (1994) was used as reduction of data, representation of data and verification of results. In the processing the data, the researcher first examined and encoded the data. When coding the data, concepts and themes that are important according to the research problem were highlighted. In this way, the data were summarized and the important concepts were selected. The data was visualized in the second stage through various graphs and figures. The visualization of the data is of great importance in terms of making the relations among the concepts and themes revealed evident with each other and reaching some conclusions based on these concepts, themes and relations. In the final stage, the concepts, themes and relations were interpreted, compared and confirmed. In this way, it is possible to make sense of the research results and to ensure its validity (Yıldırım \& Şimşek, 2013). Researchers state that content analysis is a research technique used to make replicable and valid inferences by interpreting and coding textual material. By systematically evaluating texts (e.g., documents, oral communication, and graphics), qualitative data can be converted into quantitative data (Duriau, Reger \& Pfarrer, 2007). For enabling the ethical security, the participant names were hidden and the researcher guaranteed this. For that reason, in the research, the participants were coded as $P_{1}, P_{2}$, etc. $P_{1}$ refers to the first participant, $P_{2}$ the second participant and so on.

\section{Credibility and Validity of the Research}

Validity in qualitative research means that the researcher should present the phenomenon that he/she is investigating as much as possible and in a way that reflects the truth. In order to be able to determine the data and the phenomenon, the researcher should apply to some methods such as diversity, participant confirmation, colleague confirmation (Yıldırım \& Şimşek, 2013). In this context, the participants were asked to confirm the data collected in the interviews. In order to maximize sampling, the participants were selected from different demographics and schools. The reliability of the research was also increased by taking the participant confirmation to ensure memberchecking strategy in the analysis of the data. For the validity of the "interview form", expert opinion was consulted. The draft form was applied to three teachers and according to their feedback; the expressions that were not understood well were clarified and revised. These three participants in the pre-application were not included in the study group.

In order to ensure the validity of the research, the personal characteristics of the participants were detailed in terms of their personal and social features. In addition, the interview processes, data collection and analysis processes were explained in detail. In this context, other researchers who want to conduct similar research should consider these definitions when selecting a working group. In this way, the external reliability of the study was taken into consideration. In order to ensure the internal reliability of the research, direct quotations from the statements the participants were given directly. Yıldırım and 
Şimşek (2013) state that the descriptions enriched with direct quotations would increase the internal reliability of the research.

\section{Findings}

The findings of the study were visualized using the tables and presented below.

\section{Reducing the Harms of Rumors}

Within the scope of the research, the first question of the interview was "How can the harmful aspects of the rumors in schools be reduced?". By analyzing the answers of the teachers some categories and themes were created. Table 1 shows the categories, themes and frequencies of the participants' views related to this finding.

Table 1. The themes, categories and frequencies of the participants' views about reducing the harms of rumors

\begin{tabular}{|c|c|c|c|}
\hline Themes & Categories & Participants & $\mathbf{N}$ \\
\hline \multirow{3}{*}{ 1. Giving Information } & Awareness trainings & $\begin{array}{l}P_{3}, P_{5}, P_{6}, P_{10}, P_{16}, P_{17}, P_{21} \\
P_{24}, P_{28}, P_{31}\end{array}$ & 10 \\
\hline & Informative meetings & $\mathrm{P}_{10}, \mathrm{P}_{14}, \mathrm{P}_{20}, \mathrm{P}_{24}, \mathrm{P}_{26}$ & 5 \\
\hline & Communication, values seminars & $P_{3}, P_{8}, P_{11}, P_{24}$ & 4 \\
\hline \multirow{4}{*}{$\begin{array}{l}\text { 2. Arrangement of the } \\
\text { organizational } \\
\text { environment }\end{array}$} & Effective communication & $\begin{array}{l}\mathrm{P}_{1}, \mathrm{P}_{3}, \mathrm{P}_{4}, \mathrm{P}_{8}, \mathrm{P}_{10}, \mathrm{P}_{14}, \mathrm{P}_{16} \\
\mathrm{P}_{19}, \mathrm{P}_{20}\end{array}$ & 9 \\
\hline & Transparent management & $P_{3}, P_{14}, P_{24}, P_{30}$ & 4 \\
\hline & Formal communication channels & $P_{3}, P_{5}, P_{6}, P_{15}$ & 4 \\
\hline & Reaction & $P_{7}, P_{19}, P_{23}, P_{25}, P_{33}$ & 5 \\
\hline $\begin{array}{l}\text { 3. Reaching the source } \\
\text { of the rumor }\end{array}$ & The first source of information & $\begin{array}{l}P_{1}, P_{2}, P_{3}, P_{7}, P_{9}, P_{11}, P_{12}, P_{15} \\
P_{18}, P_{23}, P_{25}, P_{27}, P_{29}, P_{32}\end{array}$ & 14 \\
\hline 4. Socialization & Social activities & $\mathrm{P}_{13}, \mathrm{P}_{17}, \mathrm{P}_{24}$ & 3 \\
\hline
\end{tabular}

As seen in Table 1, the teachers participating in the research put forward various views related to reducing the harms of rumors in schools. As the result of content analysis, these views were examined under four themes as "giving information, arrangement of the organizational environment, reaching the source of the rumor, and socializing". The themes and the categories that constitute them are presented in detail below.

\subsection{Informative Seminars on Rumors}

The teachers who participated in the study stated that some seminars should be organized in order to reduce the harmful aspects of the rumors. Under this theme, teachers expressed their opinions in the categories of "awareness trainings should be held, informative meetings should be held, communication and values seminars should be given". 


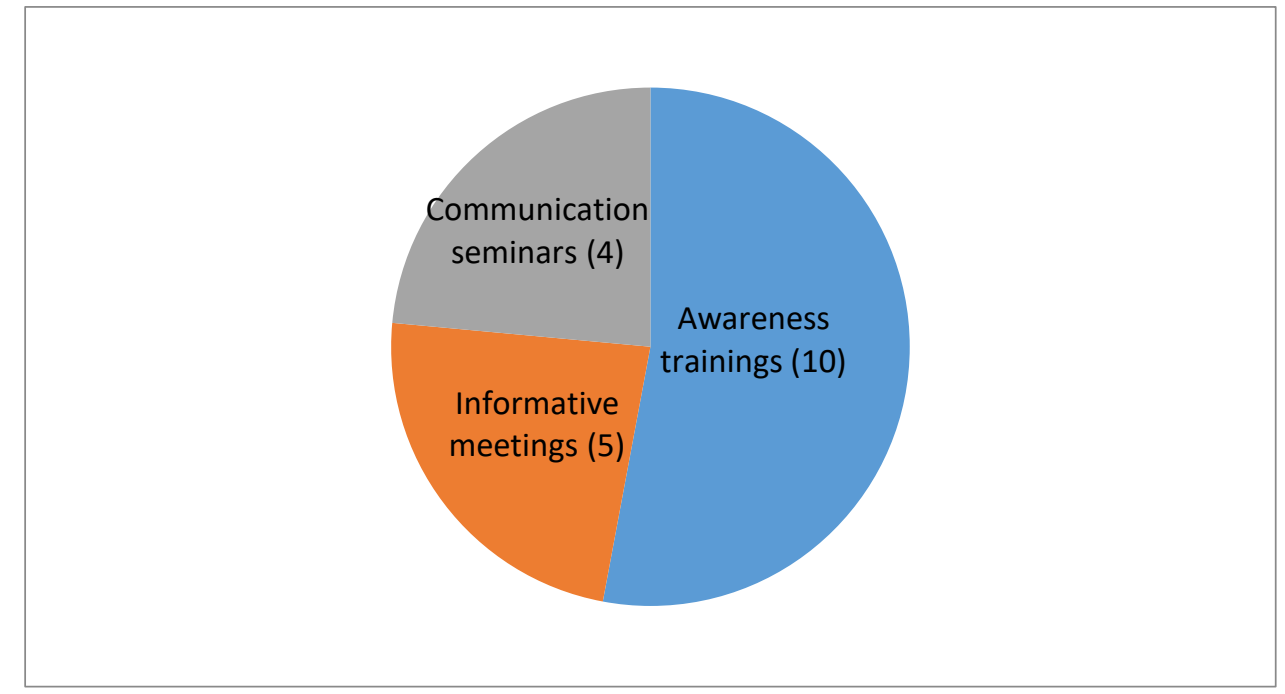

Graphic 1. Informative seminars on rumors

The views of the participants in these categories were analyzed and the findings were presented below. Some opinions of teachers in this category are as follows:

Awareness training should be given to managers about the damages of rumors $\left(P_{3}\right)$. For administrators, information may be given about the management of the rumor (P5). Seminars should be organized for the managers, teachers and employees (P6, $\left.P_{10}\right)$. The harms of rumors can be explained in the meetings ( $\left.P_{21}, P_{28}\right)$. To classify the rumors as destructive and constructive and to explain their results increases awareness $\left(P_{24}, P_{31}\right)$. These issues can be included in the in-service trainings $\left(P_{17}, P_{1} 6\right)$. Clear information can be given to employees about new situations $\left(P_{10}\right)$. Information messages can be sent from whatsapp groups ( $\left.P_{14}\right)$. Administrators can prevent destructive rumors with onsite and timely information ( $\left.P_{20}, P_{2} 6\right)$. Regular information meetings should be organized ( $\left.P_{24}\right)$. Teachers can be trained on communication skills in order to prevent destructive rumors $\left(P_{11}, P_{24}\right)$. Employees can be trained in the context of values education $\left(P_{3}, P 8\right)$.

\subsection{Arrangement of the Organizational Environment}

The teachers in the research stated that the organizational environment of schools should be organized in order to reduce the harmful aspects of the rumors. Under this theme, in order to reduce the harms of rumors, teachers expressed opinions in the categories of "effective communication should be ensured, transparent management should be adopted, formal communication channels should be activated and reaction should be given". 


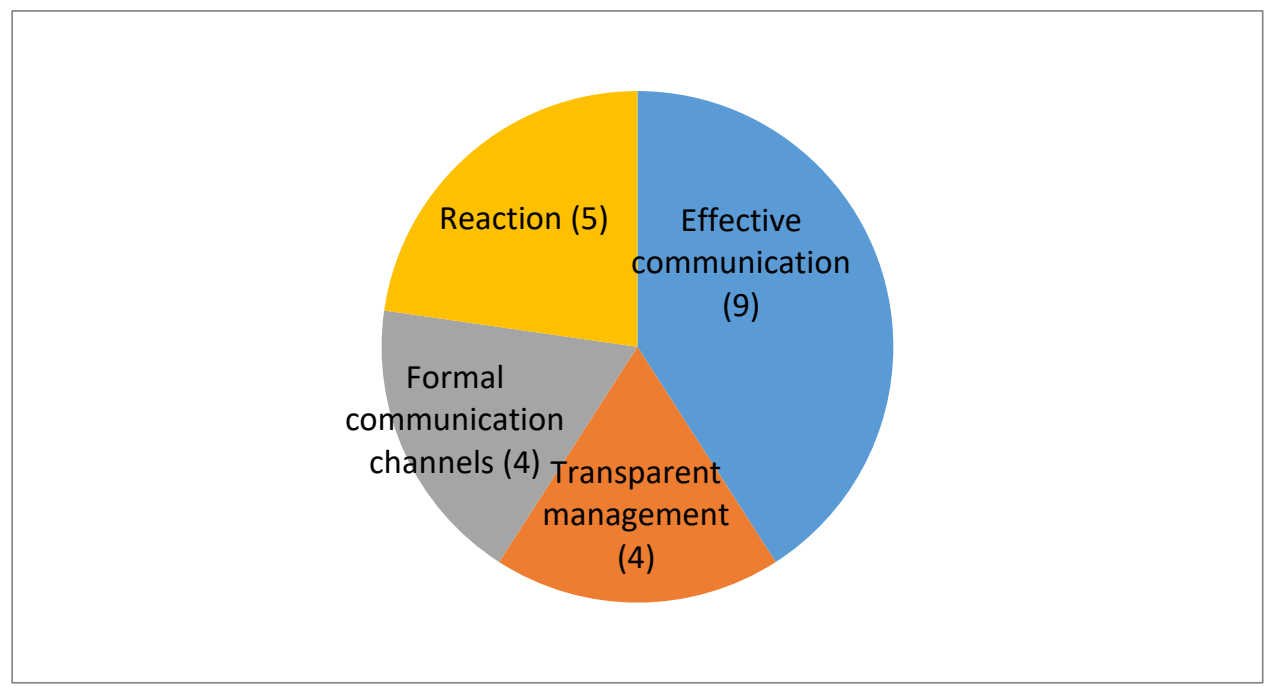

Graphic 2. Arrangement of the organizational environment

The views of the participants in these categories were analyzed and the findings were presented below. Some of the direct statements of the teachers who expressed their opinions in this category are as follows:

School administrators can reduce the harms of rumors by establishing effective communication $\left(P_{1}, P_{4}\right)$. Managers and employees should improve their communication skills ( $\left.P_{3}\right)$. Communication disturbances among employees should be eliminated and a healthy communication environment should be provided (P8, P14). Positive relationships between managers and teachers should be increased $\left(P_{10}\right)$. With effective communication within the organization, harmful aspects of rumors can be reduced $\left(P_{16}, P_{19}, P_{20}\right)$. Management should follow a more transparent and reassuring policy $\left(P_{3}, P_{14}\right)$. Transparent management should be adopted at schools ( $\left.P_{24}, P_{30}\right)$. In order to reduce the damages of the rumor, the principals should communicate the most accurate information through formal channels to the employees on time $\left(P_{3}\right)$. Administrators should keep communication channels open ( $\left.P_{5}\right)$. Administrators should avoid obstruction of communication channels (P6, $\left.P_{15}\right)$. In schools, warnings can be made to prevent rumors from affecting relationships $\left(P_{19}, P_{33}\right)$. Trying to prevent the spread of negative rumors in the environment... (P7, $\left.P_{23}, P_{25}\right)$.

\subsection{Reaching the Source of Rumor}

The teachers interviewed within the scope of the research stated that in order to reduce the harmful aspects of the rumor, the first source of this rumor should be detected when a rumor is heard in schools. The followings are examples of participants' views:

Getting the rumor from the first source of information as soon as possible can prevent the negative effects of the rumor $\left(P_{2}, P_{1}\right)$. The manager must learn the truth of the circulating rumors to reduce the harms of the rumor $\left(P_{3}, P_{7}\right)$. First, the source of the rumor can be identified and the correct information can be disseminated ( $\left.P_{9}, P_{11}\right)$. It can be reduced by reaching the right source $\left(P_{18}, P_{25}, P_{29}\right)$. 


\subsection{Providing Socialization}

The teachers who participated in the study stated that common social activities should be organized in order to reduce the harmful aspects of the rumors in schools. Some of the expressions of the teachers who expressed their opinions in this category are as follows:

This problem can be solved by directing teachers to social and cultural activities ( $P_{13}$,

$\left.P_{17}\right)$. Social activities, trips, camps etc. where people will know each other correctly should be prepared (P24).

\section{Findings on Using the Positive Aspects of Rumor in Favor of the Organization}

Within the scope of the research, the teachers were asked the question of "How do you think the positive aspects of the rumors in schools can be used in favor of the organization?". The answers were analyzed and various categories and themes were created. Table 2 shows the categories, themes and frequencies of the participants' views regarding this finding.

Table 2. Themes, categories and frequencies of opinions on using the positive aspects of rumor in favor of the organization

\begin{tabular}{|c|c|c|c|}
\hline Theme & Category & Participants & $\mathbf{N}$ \\
\hline \multirow{3}{*}{$\begin{array}{l}\text { 1. Social } \\
\text { relations }\end{array}$} & Improving intimate relationships & $\begin{array}{l}\mathrm{P}_{1}, \mathrm{P}_{4}, \mathrm{P}_{5}, \mathrm{P}_{8}, \mathrm{P}_{9}, \mathrm{P}_{11}, \mathrm{P}_{15}, \mathrm{P}_{21} \\
\mathrm{P}_{24}, \mathrm{P}_{26}, \mathrm{P}_{27}, \mathrm{P}_{28}, \mathrm{P}_{32},\end{array}$ & 13 \\
\hline & Joining the group & $\begin{array}{l}\mathrm{P}_{5}, \mathrm{P}_{7}, \mathrm{P}_{8}, \mathrm{P}_{9}, \mathrm{P}_{12}, \mathrm{P}_{18}, \mathrm{P}_{21}, \mathrm{P}_{22} \\
\mathrm{P}_{23}, \mathrm{P}_{24}, \mathrm{P}_{31}\end{array}$ & 11 \\
\hline & Recognition of organization/ employee & $\begin{array}{l}P_{2}, P_{5}, P_{6}, P_{20}, P_{23}, P_{24}, P_{29} \\
P_{31}\end{array}$ & 8 \\
\hline \multirow[t]{2}{*}{ 2. Awareness } & Learning innovations/changes & $\begin{array}{l}P_{1}, P_{2}, P_{5}, P_{8}, P_{10}, P_{12}, P_{13}, P_{15} \\
P_{19}, P_{23}, P_{24}, P_{27}, P_{30}\end{array}$ & 13 \\
\hline & Understanding events & $P_{1}, P_{3}, P_{22}, P_{25}, P_{27}$ & 5 \\
\hline \multirow{3}{*}{ 3. Feedback } & Learning how applications are perceived & $P_{3}, P_{4}, P_{5}, P_{7}, P_{8}, P_{26}, P_{27}$ & 7 \\
\hline & Identifying deficiencies of works & $P_{3}, P_{16}, P_{22}, P_{29}, P_{33}$ & 5 \\
\hline & Learning the expectations of employees & $\mathrm{P}_{4}, \mathrm{P}_{12}$ & 2 \\
\hline \multirow{2}{*}{$\begin{array}{l}\text { 4. Promotion of } \\
\text { the } \\
\text { organization }\end{array}$} & Spreading the good examples & $P_{3}, P_{11}, P_{14}, P_{19}, P_{25}$ & 5 \\
\hline & Appreciation of achievements & $\mathrm{P}_{7}, \mathrm{P}_{24}$ & 2 \\
\hline
\end{tabular}

Table 2, the teachers who participated in the research put forward various opinions about using the positive aspects of the rumors circulating among teachers in favor of the organization. As a result of the content analysis, these views were examined under four themes as "social relations, awareness, feedback and promotion of the organization". The themes and the categories that constitute them are discussed in detail below.

\subsection{Developing Social Relations}

The teachers interviewed within the scope of the study stated that the positive aspects of the rumors can be used in favor of the organization. Under this theme, teachers 
expressed the positive aspects of the rumors in categories such as "improving intimate relationships, joining the groups, recognizing the organization/employees".

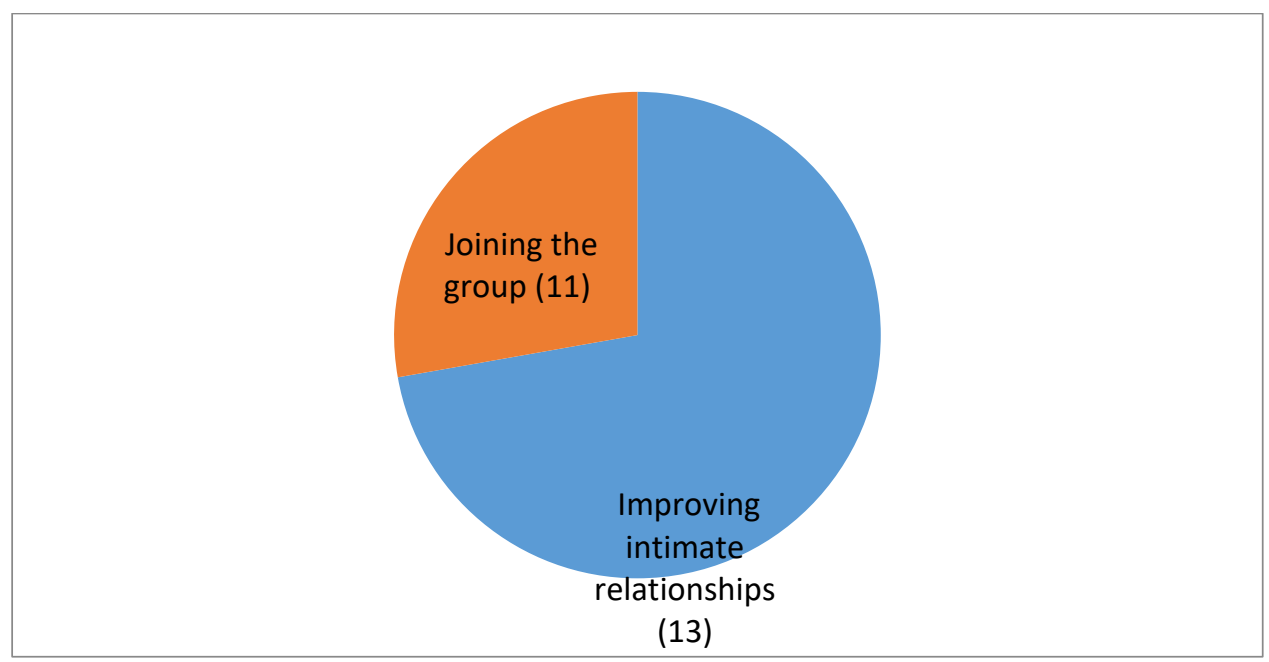

Graphic 3. Developing social relations

The views of the participants in these categories were analyzed and the findings were presented below. Some of the expressions of the teachers who expressed their opinions in this category are as follows:

Rumors contribute to the development of relationships within the school ( $\left.P_{4}, P_{5}\right)$. When we enter an environment, we develop some kind of relationship with rumors $\left(P_{1}\right)$. If the rumor is positive, it provides socialization within the group $\left(P 8, P_{11}, P_{2} 6\right)$. The fact that colleagues who do not speak to each other on the occasion of rumors can be used in favor of the organization ( $\left.P_{21}, P_{15}\right)$. It nourishes the spirit of sharing and friendship $\left(P_{24}, P_{32}\right)$. Rumors allow individuals to join the group and access information about people in the group (P5). Rumors may develop a sense of belonging to the group $\left(P_{7}, P_{8}\right.$, $P_{12}$ ). Common topics discussed bring people closer together, keeping the group dynamic (P9). It can be useful for teaching group norms (P22, P23, P24). Rumors allow individuals to get to know each other because it provides socialization ( $\left.P_{2}, P 6\right)$. Information about the newcomers can be obtained through rumors ( $P_{5}, P_{2}$ ). It can be informed about subjects related to individuals or groups and provides an opportunity to get to know the school and teachers $\left(P_{23}, P_{20}, P_{24}\right)$.

\subsection{Raising Awareness}

The teachers who participated in the research expressed various opinions that the positive aspects of the rumors could be used in favor of the organization. Under this theme, teachers expressed opinions about the positive aspects of the rumors in the categories "learning innovations/changes, understanding the insides of events". 


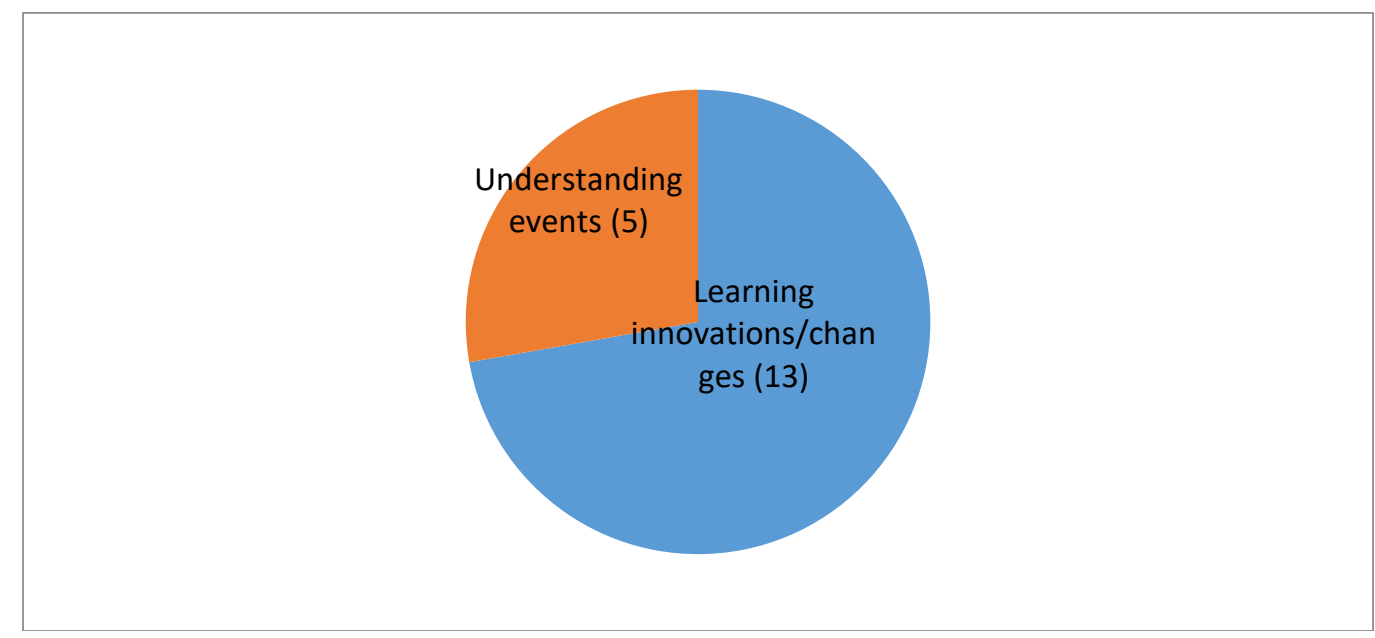

Graphic 4. Raising awareness

The views of the participants in these categories were analyzed and the findings obtained are given below. Some of the opinions of the teachers who expressed this opinion are as follows:

Through rumors, we can learn the information that is important to us in a very short time $\left(P_{1}, P_{2}\right)$. We also learn about the news, changes and regulations about the school's management and staff through rumors ( $\left.P_{2}\right)$. We learn in advance about innovations in our profession ( $\left.P_{5}, P 8\right)$. You may not be aware of the announcements on the bulletin board, but you hear everything through rumors (P23). Provides quick information acquisition ( $P_{24}$ ). It provides information about what is happening and developments in school (P27). Rumors help to learn about innovations (P30). For example, when making a decision on a subject, we can take the right steps to understand the true face of the events by starting from the rumors $\left(P_{1}\right)$. It provides insight into the events in school (P22). I think it helps to understand the inner side of events $\left(P_{27}\right)$.

\subsection{Providing Feedback}

The teachers in the study stated that the positive aspects of the rumors can be used in favor of the organization as a means of providing feedback to the management in schools. Under this theme, teachers expressed opinions about the positive aspects of the rumors in the categories of "learning how changes/practices are perceived, identifying deficiencies/problems in jobs, learning the expectations of employees". 


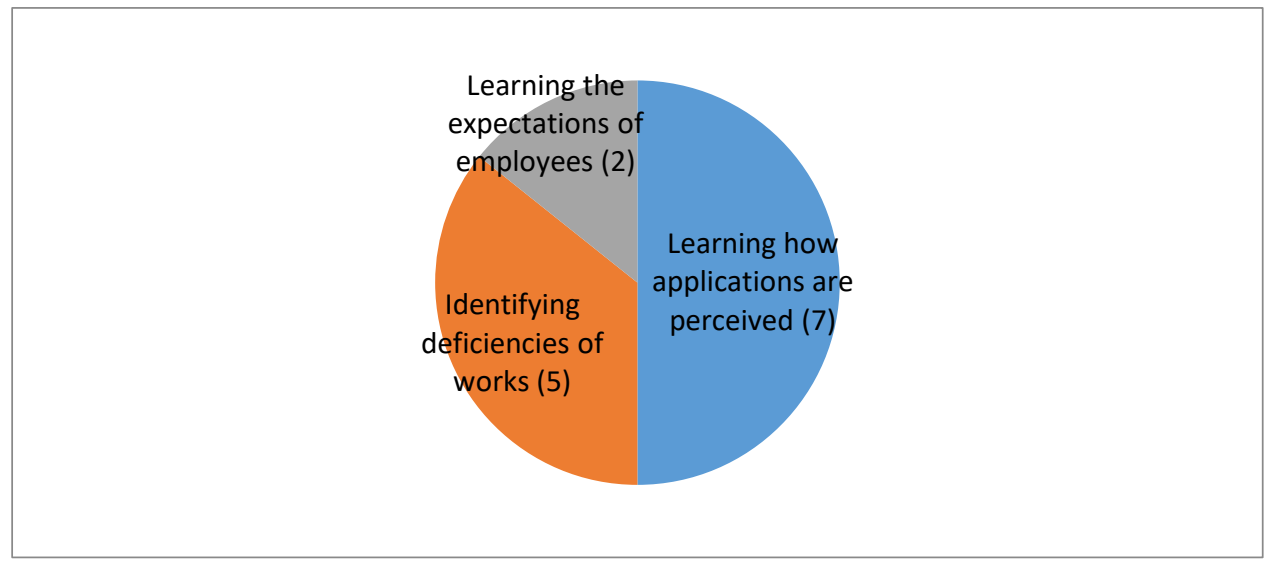

Graphic 5. Providing feedback

The views of the participants in these categories were analyzed and the findings obtained are given below. Some examples of teacher views in this category are as follows:

Rumors can be used to understand how changes are detected $\left(P_{3}, P_{4}\right)$. It provides feedback to managers about the consequences of certain situations $\left(P_{5}\right)$. Feedback to innovations and changes in the organization can be provided by rumors $\left(P_{2} 6\right)$. We learn how people in the environment give meaning on our work and thus provide feedback $\left(P_{27}\right)$. Rumors can be turned into an opportunity to identify and correct misunderstandings $\left(P_{3}\right)$. They can be used to have information about the problems in the school and can be used to find solution (P16). We can learn the problems among people from rumors $\left(P_{29}\right)$. It can be used by the manager to find out what the staff expects from management $\left(P_{4}\right)$. Preliminary research of any activity in the school can be done through rumors $\left(P_{12}\right)$.

\subsection{Promotion of the Organization}

The teachers interviewed within the scope of the research put forward some opinions that the positive aspects of the rumors can be used in favor of the organization as a means of introducing the institution to others. Under this theme, teachers expressed their views in categories such as "spreading the good examples and appreciation of achievements". Some of the teachers' views in this category are expressed as follows:

When planning activities that will have an impact on the institution, individuals can be encouraged to spread positive rumors, thus increasing their belief that good work will be done $\left(P_{3}\right)$. If rumors in the school are presented in a planned way by the administration, the organization can be used in favor of the promotional organization (P14). The environment can be informed about the achievements of the school (P1g). The appreciation of the acclaimed studies is spread by word of mouth and spoken within the school and this motivates the person (P7). The person who spreads the information is listened and appreciated at that time (P24). 


\section{Findings on Reducing the Harms of Gossip}

Within the scope of the research, the teachers were asked the question of "How do you think the harmful aspects of the gossip in schools can be reduced?". By analyzing the answers, some categories and themes were created. Table 3 lists the categories, themes and frequencies of the participants' views on this finding.

Table 3. Themes, categories and frequencies of teachers' views on reducing the harms of

\begin{tabular}{|c|c|c|c|}
\hline Themes & Categories & Participants & $\mathbf{N}$ \\
\hline \multirow{2}{*}{$\begin{array}{l}\text { 1. Informative } \\
\text { Seminars }\end{array}$} & Awareness seminars & $\begin{array}{l}P_{1}, P_{2}, P_{3}, P_{5}, P_{7}, P_{10}, P_{14}, P_{24}, P_{25} \\
P_{28}\end{array}$ & 10 \\
\hline & Value-adding seminars & $P_{3}, P_{5}, P_{8}, P_{9}, P_{10}, P_{15}, P_{17}, P_{18}, P_{25}$ & 9 \\
\hline \multirow{3}{*}{$\begin{array}{l}\text { 2. Arrangement of } \\
\text { organizational } \\
\text { environment }\end{array}$} & $\begin{array}{l}\text { Improving cooperation and } \\
\text { communication }\end{array}$ & $\begin{array}{l}P_{3}, P_{4}, P_{6}, P_{8}, P_{10}, P_{16}, P_{22}, P_{23}, P_{24} \\
P_{26}\end{array}$ & 10 \\
\hline & Giving reaction & $P_{7}, P_{11}, P_{12}, P_{14}, P_{19}, P_{30}$ & 6 \\
\hline & $\begin{array}{l}\text { Fair and transparent } \\
\text { management }\end{array}$ & $P_{3}, P_{6}, P_{13}$ & 3 \\
\hline 3. Gossip source & $\begin{array}{l}\text { Reaching he first source of } \\
\text { information }\end{array}$ & $\begin{array}{l}\mathrm{P}_{7}, \mathrm{P}_{8}, \mathrm{P}_{9}, \mathrm{P}_{11}, \mathrm{P}_{18}, \mathrm{P}_{20}, \mathrm{P}_{22}, \mathrm{P}_{24}, \mathrm{P}_{27} \\
\mathrm{P}_{32}\end{array}$ & 10 \\
\hline
\end{tabular}

As can be seen in Table 3, the teachers in the research put forward some opinions in order to reduce the harms of gossip in schools. As a result of the content analysis, these views were examined under three themes as "informative seminars, organizational environment and gossip source". The themes and the categories are given in detail below.

\subsection{Informative Seminars on Gossip}

The teachers participating in the research stated that various informative seminars should be organized in order to reduce the harmful aspects of the gossip. Under this theme, teachers expressed their opinions about the harms of gossip in the categories such as "awareness seminars and value-raising seminars" should be held.

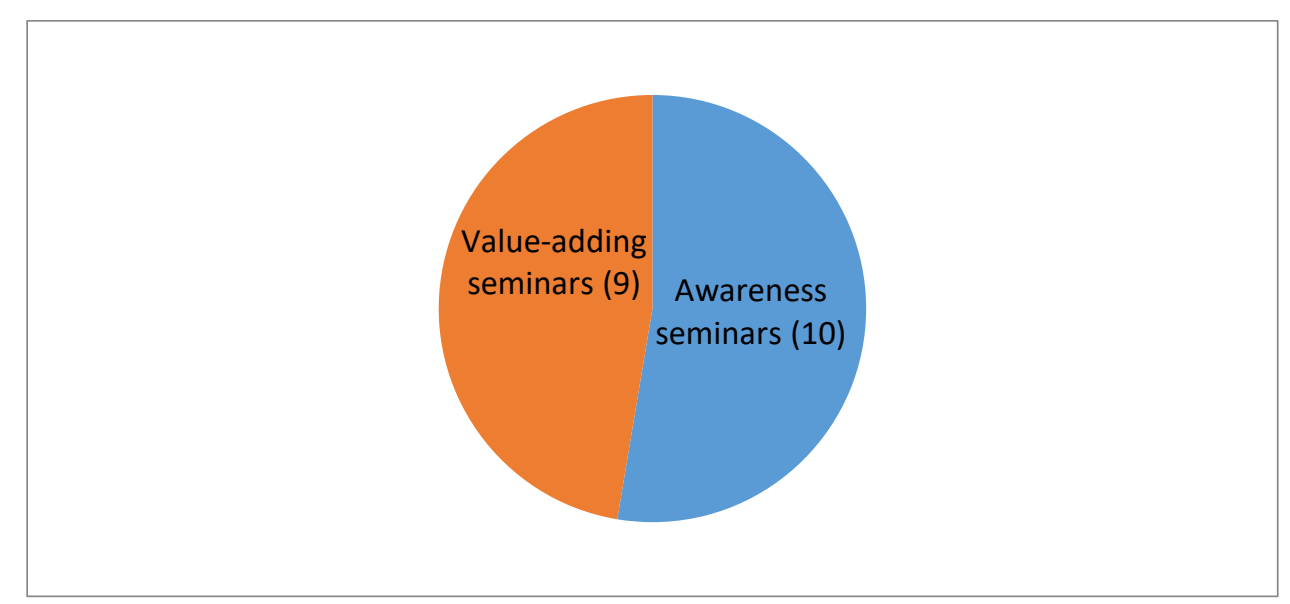

Graphic 6. Informative seminars on gossip 
The views of the participants in these categories were analyzed and the findings were presented below. Some of the views of teachers in this category are as follows:

First of all, training should be given about gossip and explanation should be made so that it can be prevented $\left(P_{1}\right)$. Managers can be given awareness training against the harmful effects of gossip $\left(P_{5}, P_{3}\right)$. Information should be provided on this subject that affects human life $\left(P_{25}, P_{2} 8\right)$. Teachers should be trained on the harmful effects of gossip ( $\left.P_{5}\right)$. Empathy training should be considered to avoid disruptive gossip (P8, P9). Activities that allow people to empathize should be done $\left(P_{15}, P_{10}, P_{18}, P_{25}\right)$. By providing ethical values education to teachers and students ( $P$ 21).

\subsection{Organizational Environment}

The teachers interviewed within the scope of the research stated that the organizational environment of schools should be arranged in order to reduce the harmful aspects of gossip. Under this theme, teachers expressed their opinions about the harms of the gossip in the categories as "cooperation and communication should be improved, fair and transparent management should be adopted and reaction should be given".

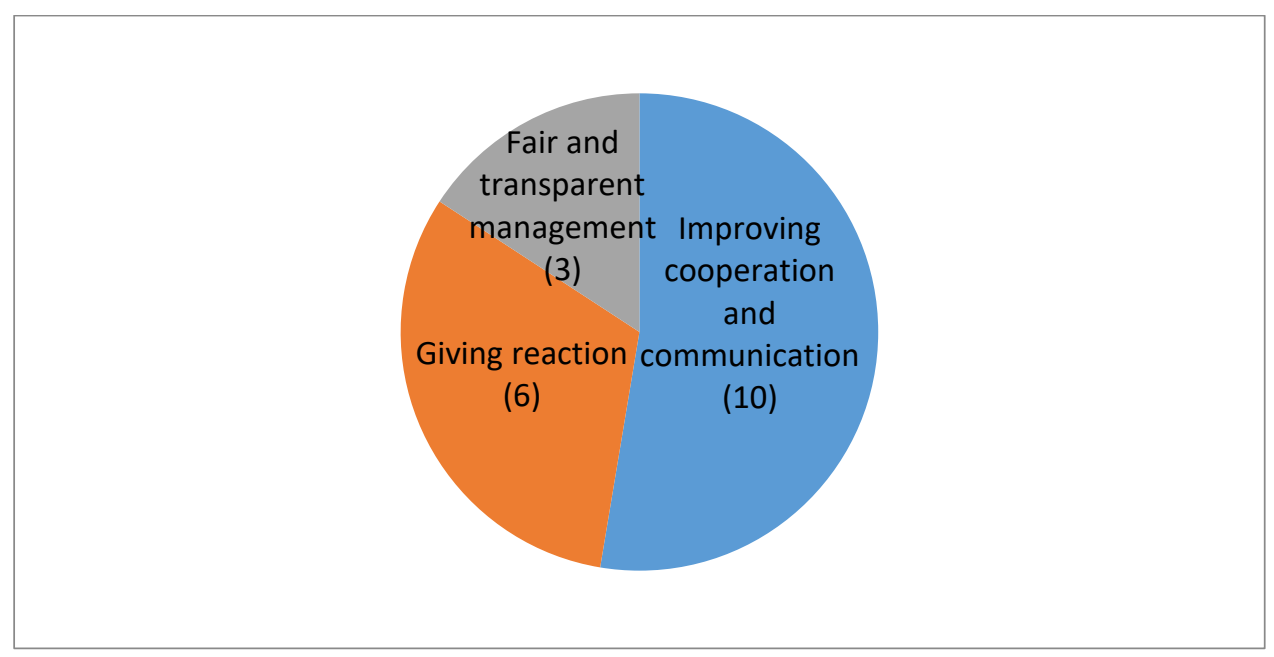

Graphic 7. Organizational environment

Some of the expressions of the teachers who expressed their opinions in this category are as follows:

In order to avoid negative gossip, management should adopt a strengthening cooperation (P8). Harmful aspects can be reduced by making everyone feel that they are part of the organization ( $\left.P_{1} 6\right)$. 'We' consciousness should be developed instead of ' 1 ' $\left(P_{24}\right)$. Environments where individuals can talk to each other clearly should be established (P4). Communication among employees should be strengthened (P6). Developing communication skills and using healthy communication methods ( $\left.P_{24}\right)$. Gossipers should be reacted ( $\left.P_{11}, P_{30}\right)$. Gossip can be prevented by showing no tolerance and excluding those who do such actions from the organization ( $\left.P_{14}\right)$. Teachers can interrupt gossip by not tolerating them (P1g). Management should be 
transparent, give confidence to the staff and rely on the people ( $\left.P_{3}\right)$. Managers should act transparently in their decisions and practices and treat all employees equally. In institutions where justice is lacking, gossip increases and thus the gossip decreases with

the establishment of justice (P6). Management prevents this by making fair practices (P13).

\subsection{Reaching the Source of Gossip}

The teachers interviewed within the scope of the research stated that when a gossip is heard in schools, the first source should be detected in order to reduce the harmful aspects of this gossip. The following statements are examples of participants' views:

The source of gossip can be reached and the truth can be revealed (P7). The reliability of the information can be learned by referring to the primary source (P8, P9). Reaching the right source and getting clear information $\left(P_{18}, P_{20}\right)$. Reaching the source of the gossip may create a solution $\left(P_{22}, P_{32}\right)$.

\section{Findings on Using the Positive Aspects of Gossip in Favor of the Organization}

Within the scope of the research the teachers were asked the question of "How do you think the positive aspects of gossip in schools can be used in favor of the organization?". The answers were analyzed and some categories and themes were created. Table 4 shows the categories, themes and frequencies of the participants' views regarding this finding.

Table 4. Themes, categories and frequencies of teacher views on using positive aspects of gossip in favor of organization

\begin{tabular}{|c|c|c|c|}
\hline Themes & Categories & Participants & $\mathrm{N}$ \\
\hline \multirow{2}{*}{$\begin{array}{l}\text { 1. Getting } \\
\text { information }\end{array}$} & A tool to know people & $\begin{array}{l}\mathrm{P}_{1}, \mathrm{P}_{3}, \mathrm{P}_{4}, \mathrm{P}_{5}, \mathrm{P}_{8}, \mathrm{P}_{9}, \mathrm{P}_{11}, \mathrm{P}_{12}, \mathrm{P}_{13} \\
\mathrm{P}_{16}, \mathrm{P}_{19}, \mathrm{P}_{24}, \mathrm{P}_{28}\end{array}$ & 13 \\
\hline & $\begin{array}{l}\text { The way of learning new/hidden } \\
\text { things }\end{array}$ & $\begin{array}{lllllll}\mathrm{P}_{1}, & \mathrm{P}_{2,} & \mathrm{P}_{5}, & \mathrm{P}_{6}, & \mathrm{P}_{8}, & \mathrm{P}_{9}, & \mathrm{P}_{12}, \\
\mathrm{P}_{24,}, \mathrm{P}_{27,} \mathrm{P}_{29} & & & & \\
\end{array}$ & 10 \\
\hline \multirow{3}{*}{ 2. Socialization } & Improving communication / sincerity & $\begin{array}{l}\mathrm{P}_{2}, \mathrm{P}_{3}, \mathrm{P}_{5}, \mathrm{P}_{7}, \mathrm{P}_{8}, \mathrm{P}_{9}, \mathrm{P}_{11}, \mathrm{P}_{12}, \mathrm{P}_{15} \\
\mathrm{P}_{18}, \mathrm{P}_{25}, \mathrm{P}_{26}, \mathrm{P}_{27}, \mathrm{P}_{30}, \mathrm{P}_{31}\end{array}$ & 15 \\
\hline & Ensuring group unity & $\begin{array}{l}P_{1}, P_{4}, P_{16}, P_{18}, P_{20}, P_{22}, P_{23}, P_{24}, \\
P_{25}, P_{27}, P_{32}\end{array}$ & 11 \\
\hline & $\begin{array}{l}\text { Entertainment and social acceptance } \\
\text { tool }\end{array}$ & $\mathrm{P}_{1}, \mathrm{P}_{2}, \mathrm{P}_{4}, \mathrm{P}_{7}, \mathrm{P}_{11}, \mathrm{P}_{25}, \mathrm{P}_{27}$ & 7 \\
\hline \multirow{2}{*}{ 3. Feedback } & Recognition of problems & $\mathrm{P}_{4}, \mathrm{P}_{5}, \mathrm{P}_{7}, \mathrm{P}_{10}, \mathrm{P}_{16}, \mathrm{P}_{17}, \mathrm{P}_{19}, \mathrm{P}_{30}$ & 8 \\
\hline & Learning demands/expectations & $\mathrm{P}_{2}, \mathrm{P}_{5}, \mathrm{P}_{14}, \mathrm{P}_{26}$ & 4 \\
\hline
\end{tabular}

As can be seen in Table 4, the teachers in the research put forward various opinions about using the positive aspects of the gossip circulating among teachers in favor of the organization. As a result of the content analysis, these views were examined under three themes as "getting information, socialization and feedback". The themes and the categories are given in detail below. 


\subsection{Getting Information}

The teachers in the research expressed various opinions about the positive aspects of gossip as a means of getting information in schools in favor of the organization. Under this theme, teachers expressed their views in categories such as "a tool to know people, the way of learning new/hidden things".

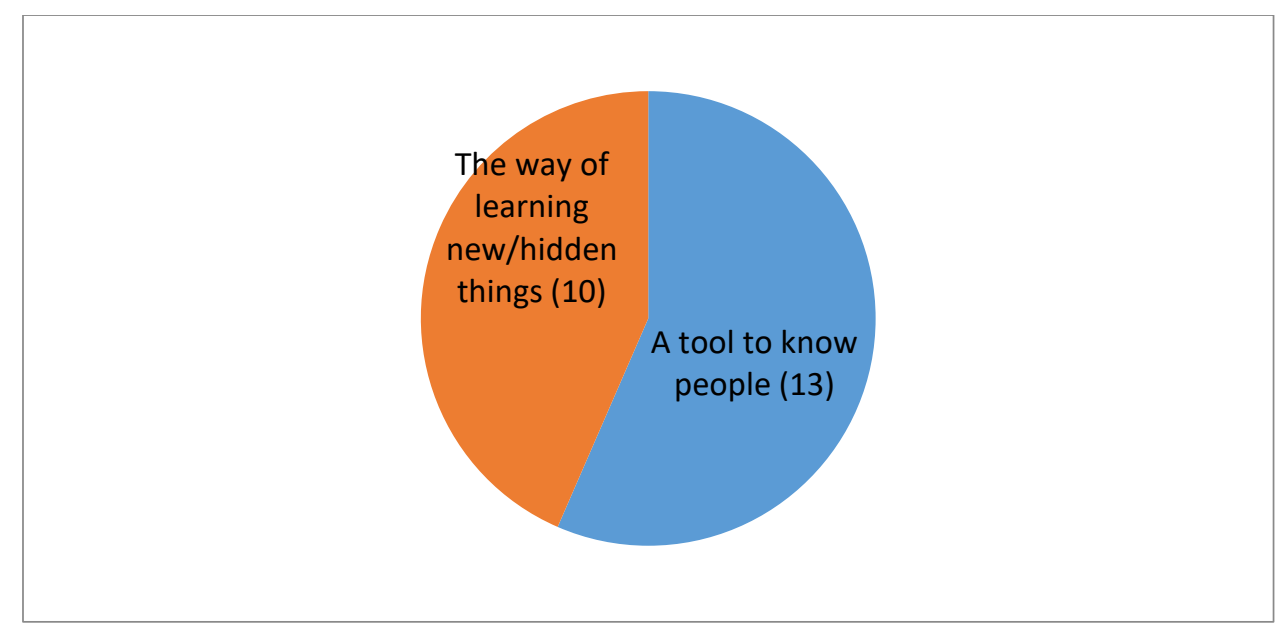

Graphic 8. Getting information

The views of the participants in these categories were analyzed and the findings are given below. Some of the teachers' views in this category are:

Through gossip, we have the opportunity to get to know people we cannot communicate with directly $\left(P_{1}, P_{4}\right)$. It can be used for quick information about the employees of the organization $\left(P_{3}\right)$. Managers can learn about the personal life of their employees through gossips ( $\left.P_{5}\right)$. Teachers can gossip to learn more about school staff and students $\left(P_{11}\right)$. Gossip can give the person the opportunity to get to know the environment in a short way (P13). We can learn the necessary information on any subject as soon as possible $\left(P_{1}\right)$. Both the manager and the employee can find out what they don't know through the gossip and reveal hidden situations ( $\left.P_{2}\right)$. The greatest benefit of gossip to institutions is that it causes rapid information exchange between individuals (P6). Through gossip we can learn about people that we need to know, without asking them (P29).

\subsection{Socialization Tool}

The teachers in the research expressed various opinions that positive aspects of gossip can be used in favor of the organization as a means of developing social relations. Under this theme, the teachers expressed their opinions in the categories of "increasing communication/sincerity, ensuring group unity, entertainment and social acceptance tool". 


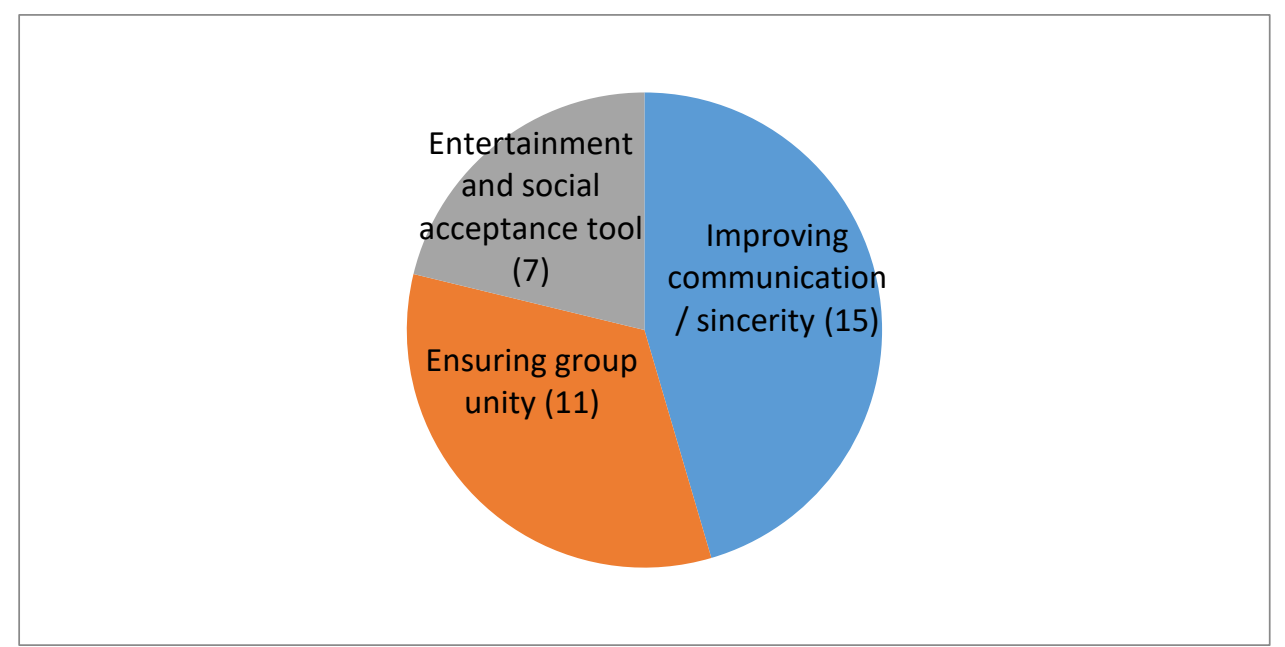

Graphic 9. Socialization tool

Some of the teachers' opinions are as follows:

Gossip strengthens intimacy within the group $\left(P_{5}, P 8\right)$. They begin to talk, meet and share with each other during transferring the gossips $\left(P_{2}\right)$. Gossip can be considered as an important tool in establishing personal relationships $\left(P_{12}, P_{15}\right)$. Since there is a sharing among individuals, it enables the development of relationships $\left(P_{2} 6\right)$. People meet with gossip on a common ground and form a group $\left(P_{1}\right)$. The gossip environment can make employees feel like they belong to a group (P8). With gossip, people have the opportunity to get close to each other (P16). It increases the adoption of organizational culture $\left(P_{23}\right)$. It prevents the loneliness by providing the socialization of the individual $\left(P_{25}\right)$. We can use the gossips to correct people (P32). Individuals can make gossips for fun (P11). It makes them feel happy and forget about negativities in business and various fields $\left(P_{25}\right)$. Sitting and talking may comfort people $\left(P_{27}\right)$. It allows people to remain connected, accept and protect individuals within the group $\left(P_{2}\right)$. If the gossips are controlled, they can realize the acceptance of the individual within the organization $\left(P_{4}\right)$.

\subsection{Providing Feedback}

The teachers interviewed within the scope of the study had some opinions that positive aspects of gossip can be used in favor of the organization as a means of providing feedback to the management in schools. Under this theme, teachers expressed their views in the categories as "recognizing problems and learning demands/expectations". 


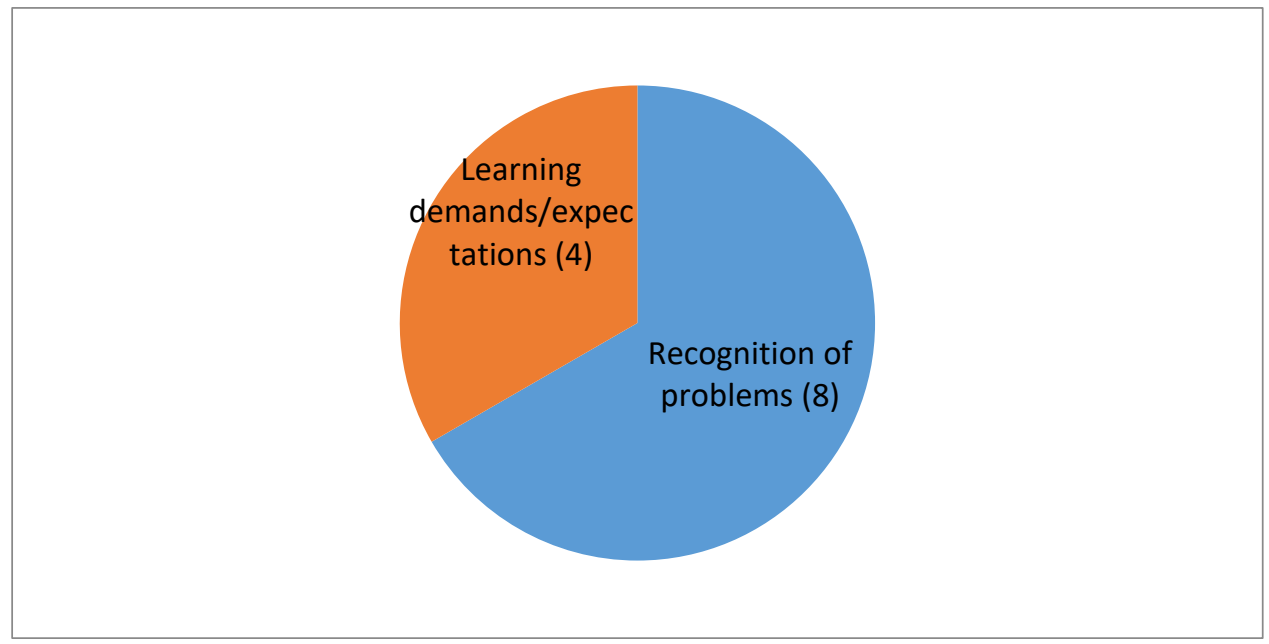

\section{Graphic 10. Providing feedback}

The views of the participants in these categories were analyzed and the findings are given below. Teacher opinions in this category are as follows:

With the help of gossips, managers get aware of the difficulties of the staff ( $P_{4}$ ). Managers can be aware of the events in the organization very quickly. Thus, it can develop quicker solutions to problems $\left(P_{5}\right)$. They have information about the problems of the individuals in the organization and they can be contacted for the solution (P16). For example, if a teacher in a school is experiencing a problem, he or she will learn from gossip and his friends can help him solve it $\left(P_{17}\right)$. Teachers can provide support to students who need support by talking among them $\left(P_{19}\right)$. For example, a person wants to be an assistant principal, but he is afraid of his principal, who can tell another manager who works at his school and talk to the principal $\left(P_{2}\right)$. If the management applies in a planned way, it can learn the requests of the employees from the organization (P14). Feedback on an issue of interest to the organization can be obtained much faster $\left(P_{5}\right)$. We can learn from the gossips about the demands of the employees in the organization (P26).

\section{E. Discussion}

This research aimed to detect the strategies to manage the organizational rumors and gossips in schools. For that reason, the teachers were interviewed. In the research, the teachers put forward various strategies in order to reduce the damages of these two types of communication. In addition, they gave some opinions to use the positive aspects of them in favor of the organization. Based on the research findings, the following results related to management of rumors and gossips were reached.

The teachers generally are in the opinion that some seminars on rumors should be organized. That result shows the participants see a deficiency in teachers' awareness on rumors. Himmetoğlu et al., (2020) state that awareness of school administrators towards the positive and negative consequences of rumor and gossip network at schools can affect organizational outcomes directly. Similarly, in this research the participant also focus on 
awareness and seminars related to rumors. The harmful rumors in school environment should be detected in order to reduce their harms. Some other research (Knapp, 1944; Kapferer, 1992; Fearn-Banks, 2007) focus on reaching the first source of rumor. By this way, the school administration can learn the truth and give this information to the teachers. Accordingly, the teachers stated that information meetings such as awareness trainings, communication seminars, values education should be organized in schools to reduce the harmful effects of rumors. An effective management technique in reducing the harmful effect of rumors is informative seminars. The teachers in this study state the need for seminars on rumors. Esposito and Rosnow (1983) suggest organizing briefing meetings with staff about the possible harms of rumor. Rivero (2013) also emphasizes establishing rumor training programs related to workplace rumors, and organizing meetings to communicate organizational changes and the latest information to the public and employees. Seminars and workplace meetings reduces the uncertainty in organizations (Kimmel, 2004; DiFonzo \& Bordia, 2007), thus they are considered as an effective strategy in the management of rumors.

In addition, in order to reduce the harmful aspects of rumors, the school's organizational environment needs to be regulated. In that sense, transparent management should be adopted, feedback mechanism should be established, effective communication should be provided, and official communication channels should be operated. In addition, the harmful aspects of the rumors in schools can be reduced by organizing common social activities and establishing an effective feedback mechanism. When the research findings in the literature are examined, it can be concluded that harmful rumors may occur in the situations such as; in the absence of effective communication (Mills, 2010; Kimmel, 2004; Çalıkuşu, et al., 2013; Koçel, 2015; Zhao, et al., 2016), low trust in the organization (Kapferer, 1992; DiFonzo \& Bordia, 2007; Koçel, 2015), insufficient information (Caplow, 1947; Kapferer, 1992; DiFonzo, Bordia \& Rosnow, 1994i Çağlar \& Kılıç, 2011; Çalıkuşu, et al., 2013). According to Liff and Wikström (2021) a manager's inappropriate behavior regarding rumors can create a poor work environment, undermine the manager's leadership, and create an unsustainable situation for that manager.

According to the teachers, the positive aspects of the rumors such as "increasing sincere relations, recognizing the organization / employees, participating in the group" can be used for the purposes of the organization. Some research in the literature suggests that rumors may increase communication among individuals (Chen, Lu \& Suen, 2016); develop social relations (Guerin \& Miyazaki, 2006); contribute to social communication (Kimmel, 2004); have a significant impact on social relations (Smith, Lucas \& Latkin, 1999). In addition, positive rumors can be used as a means of getting information such as "understanding the hidden sides of events, learning innovations and changes". The study conducted by Liff and Wikström (2021) founded the rumor as a key source of information for managers.

Moreover, rumors can be used in favor of the organization as a means of providing feedback to management in schools with functions such as "learning how 
changes/practices are perceived, identifying deficiencies/ problems in jobs and learning employees' expectations". Rumors can also be used as a means of promoting the institution in the form of "spreading good examples and appreciation of success". Some research findings in the literature suggest that rumors have positive effect on organizations such as; being used by people as a source of information to understand the environment (Jobs, 2014); containing some important information about the individual's culture (Smith, et al, 1999); serving as a function of obtaining information in uncertain and worrying situations for people (Kimmel, 2004); allowing to obtain incomplete information and sometimes confidential information (Knapp, 1944); being a means of acquiring information that is otherwise difficult to obtain (Michelson \& Mouly, 2004); being a very successful group activity for the person to obtain the information they want (Caplow, 1947). In this context, the school management should be aware of the rumors and organize seminars and meetings to reduce the harmful rumors as well as should use positive aspects of rumors in favor of organizational purposes.

Another finding of this research is related to reducing the harmful gossips. The participant teachers of this study emphasized the need of seminars including ethics and values. Accordingly, the teachers stated that various meetings such as "seminars on values, meetings, awareness seminars, in-service trainings" should be organized to reduce the damages of gossips in schools. According to the research of Han, (2019) one of the factors that lead to the emergence of gossip in organizations is employees' having various negative attitudes and emotions. Liff and Wikström (2021) also state that gossip may have negative consequences on the work environment concerning cooperation, trust, and emotions among employees. Similarly, Pheko (2018) highlights that gossips may be used for maintenance of oppression and social dominance as an expression of envy and social undermining. Accordingly, in some other research in the literature (Stewart \& Strathern, 2004; Luna \& Chou, 2013; Arabacı, et al., 2012; Çalıkuşu, et al., 2013; Eşkin-Bacaksız \& Yıldırım, 2015), it has been revealed that some negative attitudes and behaviors of individuals are the sources of especially negative gossips. In a study conducted by Han, (2021) the individual factors were the most frequent source of gossips in schools. Therefore, awareness and values seminars are considered important in reducing harmful gossips. The harmful aspects of the gossip can be reduced by "adopting fair and transparent management, providing effective communication, strengthening cooperation and sincerity, keeping formal communication channels open". In the same way, some researches in the literature (Berkos, 2003; Stewart \& Strathern, 2004; Mills, 2010) concluded that ineffective communication and problems in formal communication might cause harmful gossip in organizations. For that reason, Baker and Jones (1996) emphasized strengthening horizontal and vertical communication within the organization as management strategies to prevent or end harmful gossips in organizations. Luna and Chou (2013) also offer an open communication policy to reduce gossip among employees.

According to the other finding of this research, the teachers suggest using positive aspects of the gossips circulating among teachers in schools in favor of the organization. For this purpose, positive organizational functions of gossip such as "providing group 
unity, entertainment, increasing communication and sincerity, means of social acceptance, means of recognizing people, learning new and hidden things" can be used. Similarly, some studies (Noon \& Delbridge, 1993; Kurland \& Pelled, 2000; Berkos, 2003; Thomas \& Rozell, 2007; Grosser, Lopez-Kidwell \& Labianca, 2010; Mills, 2010; Savarimuthu, et al., 2013; Johnson, 2016; Ditmarsch, et al., 2017) suggest that gossips may have some positive function on social relations. According to Alshehre (2017) employers feel better by revealing their thoughts and ideas about something personal, and it stimulates such a person to work better. In this context, Thomas \& Rozell, (2007) also suggest the managers try to use gossips for the benefit of their organizations.

\section{F. Conclusion}

In the research, some management techniques in the management of rumors and gossips in school environment are detected. Based on the results of the research; informative seminars on awareness, communication and values should be held in order to reduce the harmful aspects of rumors and gossips. The school administration should adopt a transparent management approach, establish a feedback mechanism, provide effective communication, operate formal communication channels and react to those who spread harmful rumor and gossip. The rumors and gossips in the school can be used for organizational purposes such as; improving intimate relationships, recognizing the organization and employees, improving group cooperation and sincerity, understanding the hidden side of events, learning innovations and changes, learning how changes and practices are perceived, identifying deficiencies and problems in jobs, learning employee expectations. As a conclusion, rumors and gossips in schools can be controlled and managed effectively with using mentioned techniques.

\section{G. Limitations and Recommendations for Future Researches}

First of all, this study is a cross-sectional study. Therefore, the findings obtained in this research are limited to a limited time. Longer and longitudinal studies can be conducted. This research is a qualitative study. Therefore, the findings are limited to a specific sample group. Quantitative studies with large samples are recommended to reach more generalizable results. This research was carried out based on the opinions of the teachers, therefore, a more comprehensive researches are recommended including other stakeholders such as school administrators, parents and students.

\section{BIBLIOGRAPHY}

Adkins, K. (2017). Gossip, epistemology and power. Springer International Publishing AG, Gewerbestrasse 11, 6330 Cham, Switzerland. (eBook).

Allaoui, A. (2018). Managing gossip in organizations - a conceptual framework. Journal of Excellence for Economics and Management Research,.2(1).

Alshehre, R. A. M. (2017). Positive effects of gossiping at work. Open Journal of Medical Psychology, 6(2), 126. 
Arabacı, İ. B., Sünkür, M., \& Şimşek, F. Z. (2012). Öğretmenlerin dedikodu ve söylenti mekanizmasına ilişkin görüşleri: Nitel bir çalışma. Kuram ve Uygulamada Eğitim Yönetimi. 18(2), 171-190.

Askarizadeh, M., \& Ladani, B. T. (2021). Soft rumor control in social networks: Modeling and analysis. Engineering Applications of Artificial Intelligence, 100, 104198.

Atak, M. (2005). Örgütlerde resmi olmayan iletişimin yeri ve önemi. Havacılık ve Uzay Teknolojileri Dergisi. 2(2), 59-67.

Bahar, E. (2016). Iletişim. Detay Yayıncılık.

Baker, J. S. \& Jones, M. A. (1996). The Poison grapevine: How destructive are gossip and rumor in the workplace? Human Resource Development Quarterly, 7(1).

Bao, Y., Yi, C., Xue, Y., \& Dong, Y. (2013). A new rumor propagation model and control strategy on social networks. In 2013 IEEE/ACM International Conference on Advances in Social Networks Analysis and Mining (ASONAM 2013) (pp. 1472-1473). IEEE.

Bektaş, M. \& Erdem, R. (2015). Örgütlerde informal iletişim süreci: Kavramsal bir çerçeve. Afyon Kocatepe Üniversitesi Iktisadi ve Idari Bilimler Fakültesi Dergisi, 17(1), 125-139.

Berkos, K. M. (2003). The effects of message direction and sex differences on the interpretation of workplace gossip. PhD Dissertation, Graduate Faculty of the Louisiana State University, USA.

Brown, M. \& Napier, A. (2004). Knowledge transfer and rumour: Have we missed something?. In fifth European Conference on Organisational Knowledge, Learning and Capabilities. Innsbruck, Austria.

Bursalıoğlu, Z. (2011). Okul yönetiminde yeni yapı ve davranış. Pegem Akademi.

Çağlar, İ. \& Kılıç, S. (2011). Eğitim fakülteleri için genel iletişim. Nobel Yayıncılık.

Çalıkuşu, E., Öz, M., Göral, B. B., Bozoğlu, A. \& Ateş, İ. (2013). İnformal iletişimin "dedikodu-söylenti" örgüt içi rolü: Bir yükseköğretim kurumunda yapılan çalışma. ICQH 2013 Proceedings Book, Sakarya.

Caplow, T. (1947). Rumors in war. Social Forces, 25(3), pp. 298-302.

Chen, G. (2019). ILSCR rumor spreading model to discuss the control of rumor spreading in emergency. Physica A: Statistical Mechanics and its Applications, 522, 88-97.

Chen, H. Lu, Y. K. \& Suen, W. (2016). The power of whispers: A theory of rumor, communication, and revolution. International Economic Review, 57(1).

Crampton, S. M., Hodge, J. W., \& Mishra, J. M. (1998). The informal communication network: Factors influencing grapevine activity. Public Personnel Management, 27(4), $569-584$.

Crescimbene, M., La Longa, F., \& Lanza, T. (2012). The science of rumors. Annals of Geophysics, 55(3), 421-425.

Dağlı, A. \& Han, B. (2018). Organizational rumor scale for educational institutions. Universal Journal of Educational Research, 6(5): 936-946.

DiFonzo, N. \& Bordia, P. (2007). Rumor psychology, social and organizational approaches. American Psychological Association, 750 First Street, NE Washington, DC. 
Difonzo, N., Bordia, P., \& Rosnow, R. L. (1994). Reining in rumors. Organizational Dynamics, 23, 47-62.

Ditmarsch, H., Van Eijck, J., Pardo, P., Ramezanian, R., \& Schwarzentruber, F. (2017). Epistemic protocols for dynamic gossip. Journal of Applied Logic. 20, 1-31.

Doğan, H. (2002). İşgörenlerin adalet algılamalarında örgüt içi iletişim ve prosedürel bilgilendirmenin rolü. Ege Akademik Bakış, 2(2), 71-78.

Dores Cruz, T. D., Nieper, A. S., Testori, M., Martinescu, E., \& Beersma, B. (2020). An integrative definition and framework to study gossip. Group \& Organization Management, 46

Duriau, V. J., Reger, R. K., \& Pfarrer, M. D. (2007). A content analysis of the content analysis literature in organization studies: Research themes, data sources, and methodological refinements. Organizational Research Methods, 10(1), 5-34.

Ergin, A. (2014). Eğitimde etkili iletişim. Anı Yayıncılık.

Ersoy, F. (2017). "Fenomenoloji". Eğitimde nitel araştırma desenleri. (Ed: Ahmet Saban ve Ali Ersoy. Ankara: Anı Yayıncılık.

Eşkin-Bacaksız, F. \& Yıldırım, A. (2015). Dedikodu ve söylentiler: Hastanelerdeki durum ve hemşirelerin tutumları. Anadolu Hemşirelik ve Sağlık Bilimleri Dergisi, Sayı: 3 Cilt: 2.

Esposito, J. L. \& Rosnow, R. L. (1983). Corporate rumors: How they start and how to stop them. Management Review, 72(4), 44.

Fearn-Banks, K. (2007). Crisis communications: A casebook approach. Lawrence Erlbaum Associates Publishers.

Fine, G. A. \& Ellis, B. (2010). The global grapevine: Why rumors of terrorism, Immigration, and trade matter. Oxford University Press, Inc.

Foster, E. K. (2004). Research on gossip: Taxonomy, methods, and future directions. Review of General Psychology. 8(2), 78.

Gönen, Y. Ö., Öztürk, F. Ü., \& Efilti, S. (2008). Örgütlerde söylenti ve dedikodu. Ulusal Büro Yönetimi ve Sekreterlik Kongresi, 22-24.

Grosser, T. J., Lopez-Kidwell, V. \& Labianca, G. (2010). A social network analysis of positive and negative gossip in organizational life. Group \& Organization Management, 35(2) 177-212.

Guerin, B. \& Miyazaki, Y. (2006). Analyzing rumors, gossip, and urban legends through their conversational properties. Psychological Record. 56(1), 23.

Güllüoğlu, Ö. (2012). Örgütsel iletişim, iletişim doyumu ve kurumsal bağlıık. Eğitim Akademi Yayınları.

Han, B. \& Dağlı, A. (2018). Organizational gossip scale: Validity and reliability study. Turkish Studies Educational Sciences. Volume 13/27 p. 829-846.

Han, B. (2021). The sources of organizational gossips in schools. Education Quarterly Reviews, Vol.4 Special Issue 1, 15-24.

Han, B. (2019). İnformal iletişim biçimi olarak okullarda söylenti ve dedikodunun öğretmen görüşlerine göre incelenmesi [Investigating rumor and gossip as types of informal communication in schools according to teacher views]. Doktora tezi, Dicle Üniversitesi, Eğitim Bilimleri Enstitüsü, Diyarbakır. 
Han, B. (2020). Örgütsel söylenti ve dedikodu yönetimi. Pegem Akademi Yayınları.

Himmetoğlu, B., Ayduğ, D., \& Bayrak, C. (2020). School administrators' opinions on rumor and gossip network as an Informal communication type in schools. Çukurova Üniversitesi Eğitim Fakültesi Dergisi, 49(1), 45-72.

Hirschhorn, L. (1983). Managing rumors during retrenchment. Advanced Management Journal, $48(3), 5-11$.

Jobs, S. (2014). Uncertain knowledge. Rethinking History, 18(1), 2-9

Johnson, C. R. (2016). If you don't have anything nice to say, come sit by me: Gossip as epistemic good and evil. Social Theory and Practice, 42(2), 304-317.

Kapferer, J. N. (1992). Dünyanın en eski medyası: Dedikodu ve söylenti. (Çev. Işın Gürbüz). İletişim Yayınları.

Kieffer, C. C. (2013). Rumors and gossip as forms of bullying: Sticks and stones?. Psychoanalytic Inquiry. 33: 90-104.

Kimmel, A. J. (2004). Rumors and rumor control. Lawrence Erlbaum Associates, Inc.

Knapp, R. H. (1944). A psychology of rumor. Public Opinion Quarterly, 8(1), 22-37.

Koçel, T. (2015). Iş̧letme yöneticiliği. Beta Basım Yayıncılık.

Kurland, N. B. \& Pelled, L. H. (2000). Passing the word: Toward a model of gossip and power in the workplace. The Academy of Management Review, 25, 2; p. 428.

Liff, R., \& Wikström, E. (2021). Rumours and gossip demand continuous action by managers in daily working life. Culture and Organization, 1-20.

Lind, P. G., Silva, L. R., Andrade, J. S. \& Herrmann, H. J. (2007). The spread of gossip in American schools. Europhysics Letters (EPL). 78, 6.

Luna, A., \& Chou, S. Y. (2013). Drivers for workplace gossip: An application of the theory of planned behavior. Journal of Organizational Culture, Communications and Conflict, 17(1), 115.

Michelson, G., \& Mouly, S. V. (2004). Do loose lips sink ships? The meaning, antecedents and consequences of rumor and gossip in organizations. Corporate Communications: An International Journal. 9(3), 189-201.

Miles, M. B. \& Huberman, A. M. (2016). Nitel veri analizi. (Çev. Ed: Sadegül Akbaba Altun ve Ali Ersoy). Pegem Akademi.

Miles, M. B., \& Huberman, A. M. (1994). Qualitative data analysis: An expanded sourcebook. Sage publication.

Mills, C. (2010). Experiencing gossip: The foundations for a theory of embedded organizational gossip. Group \& Organization Management. XX(X) 1-28.

Noon, M. \& Delbridge, R. (1993). News from behind my hand: Gossip in organizations. Organization Studies. 14(1), 23-36.

Paek, H. J., \& Hove, T. (2019). Mediating and moderating roles of trust in government in effective risk rumor management: A test case of radiation-contaminated seafood in South Korea. Risk Analysis, 39(12), 2653-2667.

Patton, M. Q. (2014). Qualitative research and evaluation methods: Integrating theory and practice. Sage publications. 
Pheko, M. M. (2018). Rumors and gossip as tools of social undermining and social dominance in workplace bullying and mobbing practices: A closer look at perceived perpetrator motives. Journal of Human Behavior in the Social Environment, 28(4), 449465.

Rahmani, M. (2018). Helping program directors effectively manage rumors and gossip. Journal of Graduate Medical Education, 10(6), 616.

Ribeiro, V. E., \& Blakeley, J. A. (1995). The proactive management of rumor and gossip. The Journal of Nursing Administration, 25(6), 43-50.

Rivero, O. (2013). Rumors in the workplace affecting organizational change readiness. Global Journal of Management and Business Research Administration and Management. Volume 13 Issue 12 Version 1.

Rosnow, R. L. \& Foster, E. K. (2005). Rumor and gossip research. Psychological Science Agenda. 19(4), 1-2.

Sabuncuoğlu, Z. \& Gümüş, M. (2008). Örgütlerde iletişim. Arıkan Basım Yayım, Dağıtım Ltd. Şti.

Şantaş, G., Uğurluoğlu, Ö., Özer, Ö., \& Demir, A. (2018). Do gossip functions effect on organizational revenge and job stress among health personnel?. Journal of Health Management, 20(1), 64-72.

Savarimuthu, S., Purvis, M., Purvis, M., \& Savarimuthu, B. T. R. (2013). Gossip-based selforganising agent societies and the impact of false gossip. Minds and Machines, 23(4), 419-441.

Smith, L. C., Lucas, K. J., \& Latkin, C. (1999). Rumor and gossip: Social discourse on HIV and AIDS. Anthropology \& Medicine, 6(1), 121-131.

Stewart, P. J. \& Strathern, A. (2004). Witchcraft, sorcery, rumors, and gossip. Cambridge University Press.

Thomas, S. A \& Rozell, E. J. (2007). Gossip and nurses: Malady or remedy?. Health Care Management. 26(2):111-5.

Tripathy, R. M., Bagchi, A., \& Mehta, S. (2010). A study of rumor control strategies on social networks. In Proceedings of the 19th ACM international conference on Information and knowledge management (pp. 1817-1820).

Türnüklü, A. (2000). Eğitimbilim araştırmalarında etkin olarak kullanılabilecek nitel bir araştırma tekniği: Görüşme. Kuram ve Uygulamada Eğitim Yönetimi Dergisi, 6(4), 543559.

Uğurlu, C. T. (2014). İnformal iletişim ölçeği, geçerlik ve güvenirlik çalışması. Inönü Üniversitesi Eğitim Fakültesi Dergisi, 15(3), ss. 83-100.

Ünal-Çolak, F. (2012). "Biçimsel ve biçimsel olmayan iletişim". Iletişim. (Ed: İzlem Vural). Pegem Akademi.

Wang, Y. Q., Yang, X. Y., \& Wang, J. (2014). A rumor spreading model with control mechanism on social networks. Chinese Journal of Physics, 52(2), 816-829.

Yıldırım, A. \& Şimşek, H. (2013). Sosyal bilimlerde nitel araştırma yöntemleri. Seçkin Yayıncılık. 
Yin, R. K. (2017). Case study research and applications: Design and methods. Sage publications.

Zeng, J., Chan, C. H., \& Fu, K. W. (2017). How Social Media Construct "Truth" Around Crisis Events: Weibo's Rumor Management Strategies After the 2015 Tianjin Blasts. Policy \& Internet, 9(3), 297-320.

Zhang, P., Bao, Z., Niu, Y., Zhang, Y., Mo, S., Geng, F., \& Peng, Z. (2019). Proactive rumor control in online networks. World Wide Web, 22(4), 1799-1818.

Zhao, L., Yin, J., \& Song, Y. (2016). An exploration of rumor combating behavior on social media in the context of social crises. Computers in Human Behavior. 58, 25-36. 